\title{
Comparison of 25-Hydroxyvitamin D Levels in Acute Coronary Syndrome
}

\author{
Mirna Rahmafindari ${ }^{1}$, Leonita Anniwati ${ }^{1}$, Muh. Aminuddin ${ }^{2}$, Ferdy R Marpaung ${ }^{1}$ \\ ${ }^{1}$ Department of Clinical Pathology, Faculty of Medicine, Airlangga University/Dr. Soetomo Academic General Hospital Surabaya, Indonesia. \\ E-mail:ferdyoke@gmail.com \\ 2 Department of Cardiology and Vascular Medicine, Faculty of Medicine, Airlangga University/Dr. Soetomo Academic General Hospital, \\ Surabaya,Indonesia. E- mail: m_aminuddin@yahoo.com
}

\begin{abstract}
Vitamin D deficiency is associated with cardiovascular disease, one of which is an Acute Coronary Syndrome (ACS). Some studies provide varying results, the $25(\mathrm{OH}) \mathrm{D}$ levels, which can cause acute coronary syndrome is still controversial. This was an observational analytical study with a cross-sectional design. Samples were collected during April-September 2019 from the Dr. Soetomo Hospital, Surabaya. Patients with the ACS (70 persons) consisted of ST-Elevation Myocardial Infarction (STEMI), non-ST-Elevation Myocardial Infarction (NSTEMI), Unstable Angina (UA) were measured for 25 (OH)D and the differences in levels of $25(\mathrm{OH}) \mathrm{D}$ between groups. Examination of $25(\mathrm{OH}) \mathrm{D}$ used a competitive antibody method chemiluminescence immunoassay. There were different levels of $25(\mathrm{OH}) \mathrm{D}$ patients with ACS versus healthy persons, $p=0.0001$. There was no difference in levels of $25(\mathrm{OH}) \mathrm{D}$ in UA patients versus healthy persons, $\mathrm{p}=0.925$. Acute coronary syndrome patients had higher $25(\mathrm{OH}) \mathrm{D}$ levels than healthy persons, so it seemed that vitamin D did not play an essential role in the occurrence of ACS based on this study. This study showed that there were significant differences between $25(\mathrm{OH}) \mathrm{D}$ levels in STEMI and healthy persons, NSTEMI and healthy persons, STEMI and NSTEMI, STEMI and UA, NSTEMI and UA. In the UA group and healthy persons, no statistically significant differences were found.
\end{abstract}

Keywords: $25(\mathrm{OH}) \mathrm{D}$, STEMI, NSTEMI, unstable angina, cholecalciferol, ergocalciferol

\section{INTRODUCTION}

Vitamin $\mathrm{D}$ (calciferol) is a fat-soluble prohormone that is synthesized in the skin from 7-dehydrocholesterol through the activation of ultraviolet (UV) light. Vitamin D experiences bioactivation in the liver and kidneys and is subsequently metabolized to the active form 1,25-dihydroxyvitamin D (calcitriol). Calcitriol has a variety of biological roles, including mineral regulation, bone metabolism, tissue proliferation, and several effects on the cardiovascular system and the immune system. Some studies report that vitamin $D$ deficiency has been linked to an increased risk of various diseases, including cardiovascular disease. Vitamin $D$ deficiency in various recent studies is a risk factor for atherosclerosis which results in the occurrence of an Acute Coronary Syndrome (ACS) ${ }^{1-3}$

The prevalence of vitamin $D$ deficiency is found in almost all regions of the world, $75 \%$ is the highest in the Middle East, 6-70\% in South Asia, 10\% vitamin D deficiency in East Asia and Europe. Levels of 25-hydroxyvitamin $D\{25(\mathrm{OH}) \mathrm{D}$ or calcidiol $\}$
$>30 \mathrm{ng} / \mathrm{mL}$ are said to be deficient. Insufficient if levels of $25(\mathrm{OH}) \mathrm{D}$ are $<30$ and $>20 \mathrm{ng} / \mathrm{mL}$, and vitamin $D$ deficiency if levels of $25(\mathrm{OH}) \mathrm{D}$ are $<20 \mathrm{ng} / \mathrm{mL}^{2.4}$

Vitamin D Receptors (VDR) are present in almost all tissues, including vascular smooth muscle cells, endothelial, and myocytes. Vitamin D receptors function as mediators in the action of gene transcription factors that are expressed to most cells and tissues. The interaction of calcitriol with VDR has benefits in the cardiovascular system including reducing the production of renin, vasodilation of endothelial blood vessels, and reducing the occurrence of atherosclerosis, foam cells (foam cells), thus preventing the occurrence of Acute Myocardial Infarction (AMI). ${ }^{5.6}$

There is a significant relationship between decreased serum vitamin D levels and cardiovascular disease. This is associated with the risk of cardiovascular disease, including hypertension, diabetes, and stroke. Vitamin D deficiency can be considered a risk factor for cardiovascular disease. ${ }^{7}$

Research by Mahdavi et al. reported that patients with ACS had levels of $25(\mathrm{OH}) \mathrm{D}<20 \mathrm{ng} / \mathrm{mL}$. Lee et al. 
reported that patients with atherosclerosis who came to the hospital with a diagnosis of ACS turned out to be more likely to suffer from vitamin $D$ deficiency and had a $9 \%$ increase in the risk of death due to myocardial infarction and $25 \%$ risk of ACS including STEMI. Levels of $25(\mathrm{OH}) \mathrm{D}$ serum $<15 \mathrm{ng} / \mathrm{mL}$ caused a $17 \%$ mortality rate in 384 patients with ACS including STEMI. ${ }^{7.8}$

Eren et al. suggested that there were differences of opinion regarding the relationship between vitamin $D$ and ACS, showing 81 patients with ACS, 41 of them with STEMI. However, there was no relationship between vitamin $D$ deficiency and acute coronary syndrome. This was supported by several studies by Luis et al. who stated that many factors caused vitamin $\mathrm{D}$ deficiency including race, different individual activities, seasons, and nutritional differences. ${ }^{9,10}$

Based on this background, the researchers wanted to compare vitamin $D$ levels in patients with acute coronary syndromes and healthy persons at the Dr. Soetomo Hospital, Surabaya, and to know the vitamin D levels in healthy persons in Indonesia.

\section{METHODS}

This was an observational analytical study with a cross-sectional design. The study sample consisted of 4 groups, namely 70 patients with ACS (STEMI, NSTEMI, UA) and 30 healthy persons.

Inclusion criteria for patients with ACS were adults with complaints of chest pain and diagnosed with STEMI, NSTEMI, UA by cardiologists under the supervision of the doctor in charge supported by electrocardiography examinations read by cardiologists under the supervision of the doctor in charge and troponin examinations with a cut-off value $0.04 \mathrm{ng} / \mathrm{mL}$, and who were willingness to follow the research by signing informed consent.

In STEMI, typical ST-segment elevation persists for hours and is followed by an inversion of ST-segment depression followed by a T-wave reversal without the evolution of Q-waves, which may result from NSTEMI. Unstable angina was considered to be present in patients with ischemic symptoms suggestive of an ACS and no elevation in troponin, with or without ECG changes. Researchers grouped vitamin $D$ levels into vitamin $D$ deficiency state $(<20 \mathrm{ng} / \mathrm{mL})$, vitamin $D$ insufficiency (20-29 $\mathrm{ng} / \mathrm{mL})^{9}$

Inclusion criteria for healthy persons in healthy adults (adjusted for the age of patients with ACS) who had no complaints and did not suffer from a disease based on history taking, physical examination, and willing to participate in research by signing an informed consent.

Exclusion criteria were patients taking vitamin $D$ supplements, patients with kidney failure, and patients with liver disease.

The sample of ACS group were adults suffering from complaints of chest pain and diagnosed by STEMI, NSTEMI, UA by a cardiologist under the supervision of the doctor in charge who came to the Emergency Ward of the Dr. Soetomo Hospital Surabaya supported by electrocardiography examination which was read by a cardiologist under the supervision of the doctor in charge and troponin examination.

Healthy persons samples were all healthy adults of age (adjusted for the age of the sick population) without complaints and illness based on history taking and physical examination. All groups of patients with ACS and healthy persons who met the inclusion and exclusion criteria were examined for vitamin $D$ levels using the competitive antibody method chemiluminescence immunoassay Advia Centaur XPT made in Germany.

The study was conducted in the Clinical Pathology Laboratory Dr. Soetomo Hospital. Research samples using venous blood samples were taken as much as $5 \mathrm{~mL}$ from the mediana cubiti vein, inserted into a yellow closed vacutainer tube. The serum is stored at $-80^{\circ} \mathrm{C}$, and before running the sample had to be thawed first.

Research permission was obtained from the Health Research Ethics Committee of the Dr.Soetomo Hospital, Surabaya, with number 1241/KEPK/VI/2019.

\section{RESULTS AND DISCUSSION}

The collection of research subjects was carried out during June-August 2019, who came to the Emergency Room, and Inpatient Room of the Integrated Cardiac Care Center, Dr. Soetomo Hospital Surabaya, who was approved and the study was declared to be ethical.

Overall, the results of statistical analysis showed that there was a significant difference in gender and age with a p-value of $\leq 0.0001$ and medical history of patients with hypertension in STEMI, NSTEMI, UA, and in healthy persons, there was a significant difference with a value of $p \leq 0.0001$ (Table 1). Diabetes mellitus showed a significant difference with a value of $p=0.003$, a history of heart disease showed a statistically significant difference with $p=0.002$. Smoking habits showed statistically significant differences with 
Table 1. Characteristics of the research subjects

\begin{tabular}{lccccc}
\hline & $\begin{array}{c}\text { STEMI } \\
\mathbf{n = 3 0}\end{array}$ & $\begin{array}{c}\text { NSTEMI } \\
\mathbf{n = 3 0}\end{array}$ & $\begin{array}{c}\text { UA } \\
\mathbf{n = 1 0}\end{array}$ & $\begin{array}{c}\text { Healthy Persons } \\
\mathbf{n = 3 0}\end{array}$ & P-value \\
\hline Gender & & & & & $<0.0001$ \\
Male & $26(86.7 \%)$ & $21(70 \%)$ & $7(70 \%)$ & $10(33.3 \%)$ & \\
Female & $4(13.3 \%)$ & $9(30 \%)$ & $3(30 \%)$ & $20(66.7 \%)$ & $<0.0001$ \\
Age (years old) & & & & & \\
Median & 53 & 51.5 & 50.5 & 40.5 & \\
Minimum & 39 & 39 & 39 & 37 & \\
Maximum & 64 & 67 & 61 & 65 & \\
Medical history and & & & & & \\
risk factors & & & & 0 & 0.0001 \\
Hypertension & $12(40 \%)$ & $20(66.7 \%)$ & $4(40 \%)$ & 0.003 \\
Smoking & $16(53.3 \%)$ & $9(30 \%)$ & $5(50 \%)$ & $3(10 \%)$ & 0.003 \\
Diabetes mellitus & $4(16.7 \%)$ & $19(63.3 \%)$ & $2(20 \%)$ & 0 & 0.002 \\
Heart disease & $8(26.7 \%)$ & $9(30 \%)$ & $5(50 \%)$ & 0 & \\
\hline
\end{tabular}

Kruskal Wallis test ; $p=0.0001$

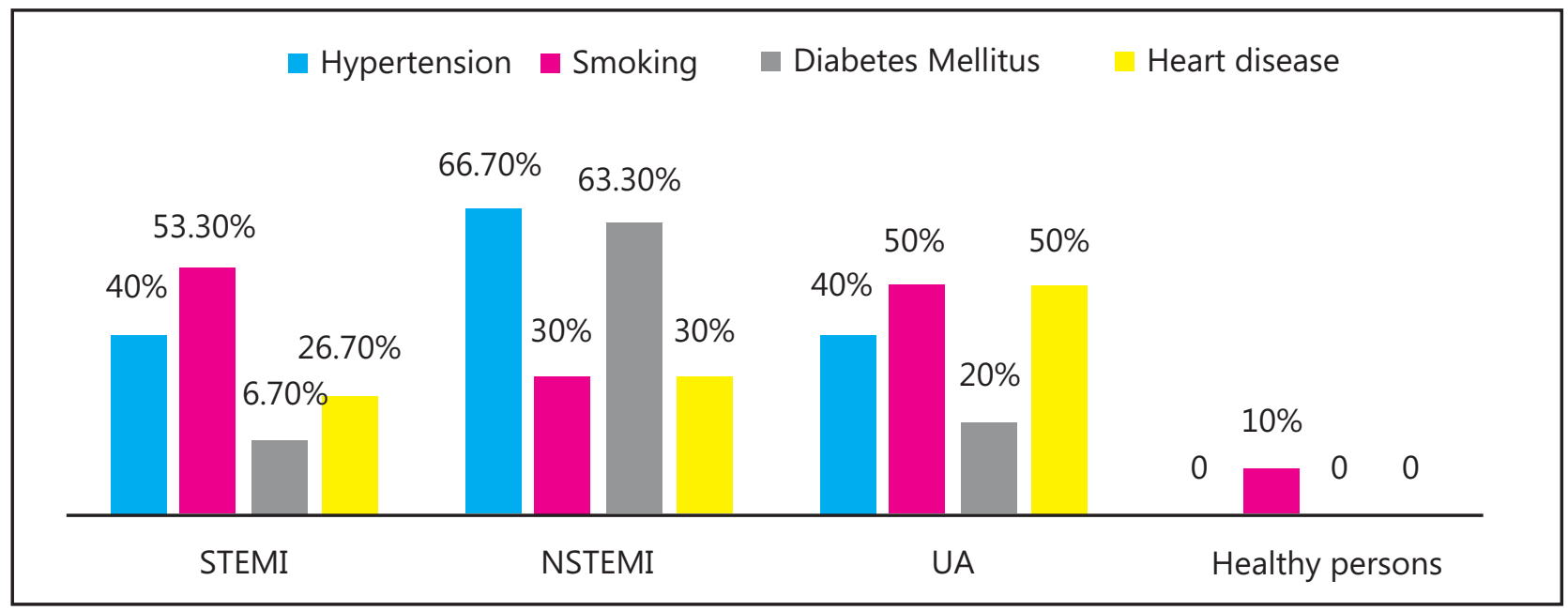

Figure 1. Bar charts of medical history percentages and patient risk factors from each group of subjects

$p=0.003$. Statistic analysis using the Kruskal Wallis test with $p \leq 0.0001$ was statistically significant (Figure 1 ).

Overall differences in serum $25(\mathrm{OH}) \mathrm{D}$ levels between groups showed significant differences with p-values $\leq 0.0001$ (Table 2).

Statistical analysis showed that there were significant differences between $25(\mathrm{OH}) \mathrm{D}$ levels in
STEMI and healthy persons ( $p \leq 0.0001)$, in NSTEMI, and healthy persons, there were significant differences ( $p \leq 0.0001$ ). There were no significant differences between levels of $25(\mathrm{OH}) \mathrm{D}$ in UA and healthy persons with a $p$-value $=0.925$. There was a significant difference between $25(\mathrm{OH}) \mathrm{D}$ levels in STEMI and NSTEMI with $p=0.008$. The STEMI and UA

Table 2. Differences in levels of $25(\mathrm{OH}) \mathrm{D}$ between groups

\begin{tabular}{lcccc}
\hline Groups & $\mathbf{n}$ (amount) & Median $(\mathbf{n g} / \mathbf{m L})$ & Minimum $(\mathbf{n g} / \mathbf{m L})$ & Maximum $(\mathbf{n g} / \mathbf{m L})$ \\
\hline STEMI & 30 & 22.67 & 14.20 & 27.12 \\
NSTEMI & 30 & 17.59 & 10.42 & 26.85 \\
UA & 10 & 8.50 & 5.93 & 23.49 \\
Healthy & 30 & 9.31 & 5.21 & 21.00 \\
persons & & & &
\end{tabular}

Kruskal Wallis test ; $p=0.0001$ 
groups showed a significant difference with a value of $\mathrm{p} \leq 0.0001$. Levels of $25(\mathrm{OH}) \mathrm{D}$ in NSTEMI and UA showed significant differences with $p=0.003$. Box plot curves of $25(\mathrm{OH}) \mathrm{D}$ levels in each study subject showed a higher median value in the STEMI group than in the other groups (Figure 2).
Percentage bar charts of vitamin D status for each group of study subjects, referring to vitamin D deficiency and vitamin D insufficiency (Figure 3 ) and some research results at $25(\mathrm{OH}) \mathrm{D}$ levels in patients with ACS and healthy people (Table 3).

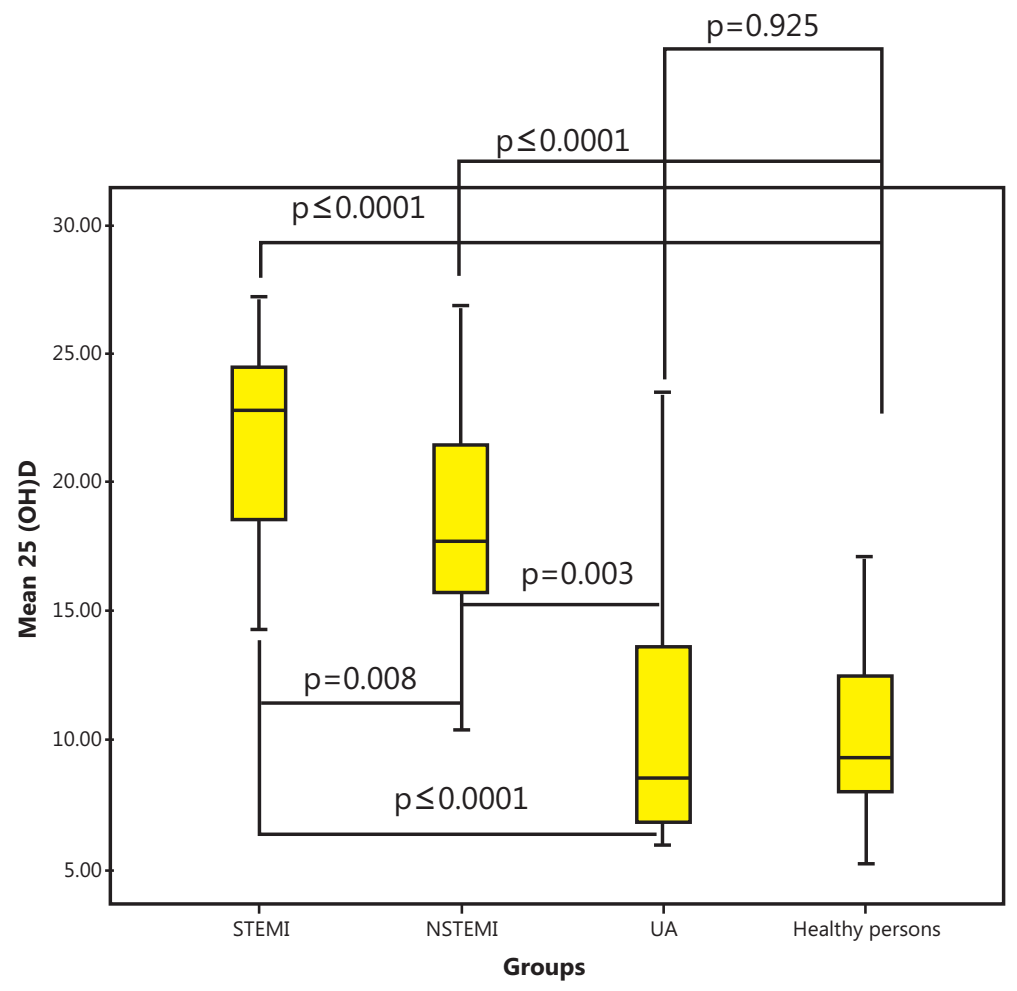

Figure 2. Box plot curves of $25(\mathrm{OH}) \mathrm{D}$ levels in each study subject showed that the median value in the STEMI group was higher than the other groups

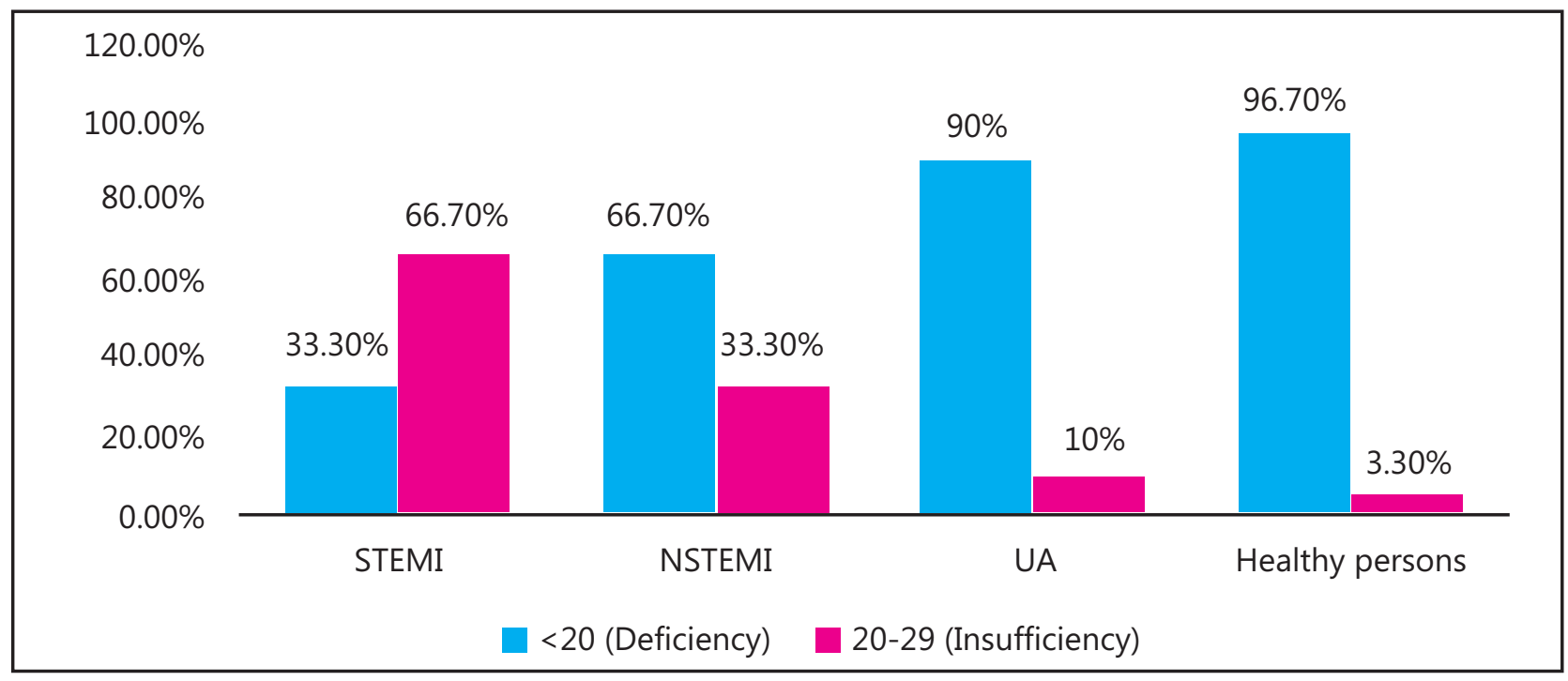

Figure 3. Bar graph of the percentage of vitamin D status for each group of study subjects 
Table 3. Results of researches on $25(\mathrm{OH}) \mathrm{D}$ levels in patients with ACS and healthy persons

\begin{tabular}{|c|c|c|c|}
\hline The Researcher & Subjects & Methods & Results \\
\hline $\begin{array}{l}\text { Malhotra and } \\
\text { Mithal, } 1970 . \\
\text { India. }^{11}\end{array}$ & $\begin{array}{l}\text { Healthy } \\
\text { persons (91\%) }\end{array}$ & - & $\begin{array}{ll}\text { Vitamin D status in Asia : } \\
\text { Indonesia } & =19.2 \mathrm{ng} / \mathrm{mL} \\
\text { Malaysia } & =17.6 \mathrm{ng} / \mathrm{mL} \\
\text { China } & =27.6 \mathrm{ng} / \mathrm{mL} \\
\text { Hong Kong } & =28.4 \mathrm{ng} / \mathrm{mL} \\
\text { Japan } & =30 \mathrm{ng} / \mathrm{mL}\end{array}$ \\
\hline $\begin{array}{l}\text { Lund et al. } 1978 . \\
\text { Denmark. }^{12}\end{array}$ & $\begin{array}{l}53 \text { STEMI and } \\
\text { NSTEMI } \\
75 \text { UA }\end{array}$ & $\begin{array}{l}\text { DEAE Sephadex ion } \\
\text { exchange } \\
\text { chromatography }\end{array}$ & $\begin{array}{l}\text { Levels of } 25(\mathrm{OH}) \mathrm{D} \text { patients } \\
\text { with AMI (STEMI, NSTEMI) and } \\
\text { UA respectively } 24 \pm 10 \mathrm{ng} / \mathrm{mL} \\
\text { and } 23.5 \pm 9.6 \mathrm{ng} / \mathrm{mL}\end{array}$ \\
\hline $\begin{array}{l}\text { Setiati, } 2008 . \\
\text { Indonesia. }^{13}\end{array}$ & $\begin{array}{l}74 \text { healthy } \\
\text { persons } \\
\text { (average age } \\
18-70 \text { years } \\
\text { old) }\end{array}$ & $\begin{array}{l}\text { ELISA method was } \\
\text { performed in the } \\
\text { clinical laboratory } \\
\text { which was } \\
\text { internationally } \\
\text { standardized (ISO } \\
9001 \text { ) }\end{array}$ & $\begin{array}{l}\text { Most Indonesians were vitamin } \\
\text { D deficient with cut-off } 25 \\
(\mathrm{OH}) \mathrm{D} 30 \mathrm{ng} / \mathrm{mL}\end{array}$ \\
\hline $\begin{array}{l}\text { Han et al. } 2011 . \\
\text { Korea. }^{14}\end{array}$ & $\begin{array}{l}\text { Healthy } \\
\text { people } 3.047 \\
\text { ` and } 3.878 \text { 우 } \\
\text { (average age } \\
20-80 \text { years } \\
\text { old) }\end{array}$ & RIA (Diasorin) & $\begin{array}{l}\text { Mean } 25(\mathrm{OH}) \mathrm{D}(\mathrm{ng} / \mathrm{mL}): \\
\text { đ }=30 \pm 1 \\
\text { 우 }=29 \pm 1 \\
\text { Mean } 25(\mathrm{OH}) \mathrm{D}<20 \mathrm{ng} / \mathrm{mL}: \\
47 \% ? \text { and } 65 \% ? \\
\text { Mean } 25(\mathrm{OH}) \mathrm{D}<30 \mathrm{ng} / \mathrm{mL}: \\
87 \% ? \text { and } 94 \% ?\end{array}$ \\
\hline $\begin{array}{l}\text { Nimithpong and } \\
\text { Holick, } 2013 \text {. } \\
\text { Thailand. }{ }^{15}\end{array}$ & $\begin{array}{l}\text { Healthy } \\
\text { people } 1.321 \\
\text { ๙ and } 1.320 \text { 우 }\end{array}$ & $\begin{array}{l}\text { LC-MS/MS } \\
\text { (Liquid } \\
\text { chromatography/tand } \\
\text { em mass } \\
\text { spectrometry) }\end{array}$ & $\begin{array}{l}\text { Mean } \pm 25(\mathrm{OH}) \mathrm{D}(\mathrm{ng} / \mathrm{mL}): \\
\text { ๙ }=53 \pm 19 \\
\text { 우 }=46 \pm 18 \\
\text { Mean } 25(\mathrm{OH}) \mathrm{D}<20 \mathrm{ng} / \mathrm{mL}: \\
2 \% \text { and } 9 \% \text { 우 } \\
\text { Mean } 25(\mathrm{OH}) \mathrm{D}<30 \mathrm{ng} / \mathrm{mL}: \\
33 \% \text { त and } 57 \% \text { 우 }\end{array}$ \\
\hline $\begin{array}{l}\text { Kirchberger et al. } \\
2015 . \\
\text { Jerman. }^{16}\end{array}$ & $\begin{array}{l}314 \text { STEMI and } \\
473 \text { NSTEMI }\end{array}$ & - & $\begin{array}{l}155(19 \%) \text { insufficiency vitamin } \\
\text { D and } 566 \text { (70\%) deficiency } \\
\text { vitamin D. There were no } \\
\text { significant differences between } \\
\text { STEMI and NSTEMI patients. }\end{array}$ \\
\hline $\begin{array}{l}\text { Mitchell et al. } \\
2017 . \\
\text { Boston. }^{17}\end{array}$ & $\begin{array}{l}170 \text { healthy } \\
\text { persons } \\
\text { (average age } \\
18-65 \text { years } \\
\text { old) }\end{array}$ & $\begin{array}{l}\text { Chemiluminescent } \\
\text { immunoassay (Abbott } \\
\text { ARCHITECT i2000, } \\
\text { Illinois, U.S.A) }\end{array}$ & $\begin{array}{l}\text { Mean } 25(\mathrm{OH}) \mathrm{D}=30 \mathrm{ng} / \mathrm{mL}: \\
34 \% \precsim \text { and } 65 \% \text { 우 } \\
\text { Mean } 25(\mathrm{OH}) \mathrm{D}=30 \mathrm{ng} / \mathrm{mL}: \\
63 \% \precsim \text { and } 37 \% \text { 우 }\end{array}$ \\
\hline $\begin{array}{l}\text { Luis et al. } 2013 . \\
\text { Brazilia. } 10\end{array}$ & $\begin{array}{l}204 \text { patients } \\
\text { with ACS }\end{array}$ & $\begin{array}{l}\text { Competitive CLIA } \\
\text { ADVIA Centaur } \\
\text { (Siemens Healthcare } \\
\text { Diagnostics). }\end{array}$ & $\begin{array}{l}\text { Mean } 25(\mathrm{OH}) \mathrm{D}=20 \mathrm{ng} / \mathrm{mL}: \\
19.5 \pm 8.2 \mathrm{ng} / \mathrm{mL}\end{array}$ \\
\hline $\begin{array}{l}\text { Eren et al. } 2014 . \\
\text { Turki. }^{9}\end{array}$ & $\begin{array}{l}47 \text { STEMI and } \\
41 \text { UA (average } \\
\text { age } 18-70 \\
\text { years old) }\end{array}$ & $\begin{array}{l}\text { Competitive CLIA } \\
\text { (LIAISON) }\end{array}$ & $\begin{array}{l}\text { Patients STEMI } \\
\text { Mean } 25(\mathrm{OH}) \mathrm{D} 20-60 \mathrm{ng} / \mathrm{mL}: \\
8.7 \pm 3.3 \\
\text { Patients UA } \\
\text { Mean } 25(\mathrm{OH}) \mathrm{D} 20-60 \mathrm{ng} / \mathrm{mL}: \\
10.7 \pm 4.5\end{array}$ \\
\hline Safaie et al. $2018 .^{18}$ & $\begin{array}{l}88 \text { STEMI and } \\
\text { NSTEMI } \\
\text { (average age } \\
\text { 18-67 years } \\
\text { old) }\end{array}$ & $\begin{array}{l}\text { Microplate Absorbance } \\
\text { Reader ( } 2020 \text { SW- } \\
\text { version } 2.0 \text { up) and } \\
\text { factory kit (Euroimmun, } \\
\text { Germany) }\end{array}$ & $\begin{array}{l}\text { Patients STEMI } \\
\text { Mean } 25(\mathrm{OH}) \mathrm{D}=20 \mathrm{ng} / \mathrm{mL} \text { : } \\
\nwarrow=13.3 \pm 7.5 \\
\text { 우 }=14 \pm 8.2 \\
\text { Patients NSTEMI } \\
\text { Mean } 25(\mathrm{OH}) \mathrm{D}=20 \mathrm{ng} / \mathrm{mL}: \\
\nwarrow=26.5 \pm 15.5 \\
\text { 우 }=17.7 \pm 10.8\end{array}$ \\
\hline $\begin{array}{l}\text { Bijaya et al. } 2018 \\
\text { India. }^{19}\end{array}$ & $\begin{array}{l}100 \text { patients } \\
\text { with ACS }\end{array}$ & - & $\begin{array}{l}\text { The level } 250 \mathrm{H}) \mathrm{D} \text { of healthy } \\
\text { persons= } 32.97 \mathrm{ng} / \mathrm{mL} \text { was higher } \\
\text { than STEMI, NSTEMI patients, } \\
\text { whereas at UA }=28.30 \mathrm{ng} / \mathrm{mL} \\
\text { which showed statistically } \\
\text { significant differences }\end{array}$ \\
\hline
\end{tabular}


The process of the mechanism of vitamin $D$ in the heart and vitamin $D$ deficiency status is mostly found in Asians. Black adults and Asians have a higher risk of vitamin $D$ deficiency. Vitamin $D$ sufficiency is more common in East Asia and Europe. This is due to more consumption of fish, fish oil, and skin and season pigmentation. ${ }^{11,12}$

Vitamin $D$ deficiency found in Indonesia according to research by Setiati, was because 38.5\% of Indonesian females only come out once a week and many wear a hijab as the most sun protection so that the subject had a long exposure to 30-60 minutes of sunshine for once a week, and average daily vitamin $D$ intake was 0.6 IU $^{13}$

Vitamin $D$ deficiency may be said only as a risk marker, not a major risk factor for cardiovascular disease. There may be other factors. The researchers found a variety of literature stating that many factors cause vitamin $D$ deficiency including race, different individual activities, seasons, and nutritional differences. ${ }^{14,15}$

The mechanism of the role of vitamin $D$ in the heart, according to Kassi et al. who stated that vitamin $\mathrm{D}$ was an anti-inflammatory by inhibiting pro-inflammatory cytokines that will inhibit plaque formation and can regulate acute vascular tonicity through the decreased molecular proliferation of smooth muscle cells in subendothelial cells. ${ }^{1}$ Vitamin $D$ could also cause the increased synthesis of antioxidant molecules in endothelial cells and decreased ROS production so that endothelial cells were protected and reduced plaque formation. The role of vitamin $D$ could reduce the occurrence of atherosclerosis, which caused ACS. In accordance with this study which obtained low $25(\mathrm{OH}) \mathrm{D}$ levels in patients with the syndrome, but $25(\mathrm{OH}) \mathrm{D}$ levels in healthy persons were lower. ${ }^{1}$

\section{CONCLUSION AND SUGGESTION}

There were differences in the levels of $25(\mathrm{OH}) \mathrm{D}$ in patients with the ACS with STEMI and healthy persons. There were differences in the levels of $25(\mathrm{OH}) \mathrm{D}$ in patients with the ACS with NSTEMI and healthy persons. There was no difference in levels of $25(\mathrm{OH}) \mathrm{D}$ in patients with the ACS with UA and healthy persons. There were differences in levels of $25(\mathrm{OH}) \mathrm{D}$ in patients with ACS STEMI, NSTEMI, and UA. However, $25(\mathrm{OH}) \mathrm{D}$ levels in healthy persons were lower than STEMI, NSTEMI, UA.

Not taking into account the intake of foods containing vitamin $D$, the length of exposure to sunlight could cause bias in this study. The study population was only in one geographical area resulting in vitamin $D$ state, which could change with various factors, such as season, geographical location, and sun exposure.

Further research should be carried out, taking into account the intake of foods containing vitamin D, the duration of exposure to sunlight, which could cause bias in this study. However, taking into account recruiting research subjects in various geographical areas.

\section{REFERENCES}

1. Kassi E, Adamopoulos C, Basdra E, Papavassiliou A. Role of vitamin D in atherosclerosis. Circulation, 2013; 128(3): 2517-2531.

2. Lee J, Gadi R, Spertus J, Tang F, O'Keefe J. Prevalence of vitamin $D$ deficiency in patients with acute myocardial infarction. The American Journal of Cardiology, 2011; 107(11): 1636-1638.

3. Al Mheid I, Quyyumi AA. Vitamin D and cardiovascular disease: Controversy unresolved. Journal of the American College of Cardiology, 2017; 70(1): 89-100.

4. Mithal A, Wahl D, Bonjour J, Burckhardt P, Dawson H. Global vitamin D status and determinants of hypovitaminosis D. Osteoporosis International, 2009; 20(11): 1807-1820.

5. Makoui R, Dizaji M, Khederlou H. Comparison of serum levels of vitamin $D$ in patients with and without acute coronary syndrome. International Journal Cardiovascular Practice, 2018; 3(2): 25-29.

6. Muscogiuri G, Annweiler C, Duval G, Karras S, Tirabassi G, et al. Vitamin D and cardiovascular disease: From atherosclerosis to myocardial infarction and stroke. International Journal of Cardiology, 2017; 1(230): 577-584.

7. Safaie N, Rezaee H, Dvati BS, Entezari-Maleki T. Vitamin D deficiency predicts the ST-elevation type of myocardial infarction in patients with acute coronary syndrome. Iranian Journal of Pharmaceutical Research, 2018; 17: 73-78.

8. Kestenbaum B, Katz R, Hoofnagle A, Sarnak J, Shlipak M. Vitamin D, parathyroid hormone, and cardiovascular events among older adults. Journal of the American College of Cardiology, 2011; 58(14): 1433-1441.

9. Oberoi D, Mehrotra V, Rawat A. Vitamin D as a profile marker for cardiovascular diseases. Annals of Cardiac Anaesthesia, 2019; 22(1): 47-50.

10. Eren $E$, Hamit $Y$, Necat $Y$. No association between vitamin $D$ levels and inflammation markers in patients with acute coronary syndrome. Advances in Medical Sciences, 2014; 60(1): 89-93.

11. Correia LC, Sodre F, Garcia G, Sabino M, Brito M, et al. Relation of severe deficiency of vitamin $D$ to cardiovascular mortality during acute coronary syndromes. The American Journal of Cardiology, 2013; 111(3): 321-327. 
12. Malhotra N, Mithal A. Vitamin D status in Asia. International Osteoporosis Foundation, 1970; 1-3.

13. Lund B, Badskjaer J, Soerensen OH. Vitamin D and ischaemic heart disease. Hormone and Metabolic Research, 1978; 10(6): 553-556.

14. Setiati S. Vitamin D status among Indonesian elderly women living in institutionalized care units. Acta Medica Indonesiana, 2008; 4(2): 1-6.

15. Han $S$, Han J, Hoon C, Woong H, Jung $G$, et al. Vitamin $D$ insufficiency in Korea-A greater threat to younger generation: The Korea National Health and Nutrition Examination Survey (KNHANES) 2008. Journal Clinical Endocrinology Metabolism, 2011; 96(3): 643-651.

16. Nimitphong Hataikarn, Holick MF. Vitamin D status and sun exposure in Southeast Asia. Dermato-Endocrinology, 2013; 5(1): 34 - 37.

17. Kirchberger I, Wolf K, Heier M, Kuch B, von Scheidt $W$, et al. Are daylight saving time transitions associated with changes in myocardial infarction incidence?. BMC Public Health, 2015; 15(778): P1-8.

18. Mitchell D, Henao M, Finkelstein J, Bowie Burnett S. Prevalence and predictors of vitamin $D$ deficiency in healthy adults. Endocrine Practice Journal, 2017; 18(6): 914-923.

19. Bijaya M, Kumar K, Satish P. Association of vitamin D deficiency and acute coronary syndrome experience. Integrative Journal of Global Health, 2018; 2(1): 1-5. 